\title{
SOCIAL COMPETENCES AND UNSUITABLE BEHAVIOUR OF PUPILS
}

[SOCIALNE KOMPETENCIE A NEVHODNE SPRAVANIE ZIAKOV]

\author{
Ctibor Hatar - Rastislav Rosinsky
}

doi: 10.18355/PG.2019.8.1.19

\begin{abstract}
The submitted study has a theoretical character and its aim is to define the relationship between the social competences of pupils and their educationally problematic behaviour in and outside the school context. In the first chapter the authors defines and compares the concepts of competence, key competence and social competence. The second chapter is aimed at educational problems and disorders in the behaviour of pupils. And finally, in the third chapter, the authors offers possibilities of acquiring and developing social competences of pupils in order to prevent their unsuitable behaviour in and outside the school context.
\end{abstract}

\section{Key words}

Social competences, educational problems, disorders in behavior, development of social competences, pupils

\section{Abstrakt}

Predkladaná štúdia teoretického charakteru si kladie za ciel' definovat' vzt'ah medzi sociálnymi kompetenciami žiakov a ich výchovne problémovým správaním v podmienkach školy i mimo nej. V prvej kapitole sa autori zaoberajú definovaním a porovnávaním pojmov kompetencia, kl’účová kompetencia a sociálna kompetencia. Druhá kapitola je zameraná na výchovné problémy a poruchy správania žiakov a v tretej kapitole autori predkladajú možnosti nadobúdania a rozvoja sociálnych kompetencií žiakov v kontexte prevencie ich nežiaduceho správania $\mathrm{v}$ škole a mimo školy.

\section{Kl’účové slová}

Sociálne kompetencie, výchovné problémy, poruchy správania, rozvoj sociálnych kompetencií, žiaci

\section{Úvod}

V súčasnosti môžeme v školskej praxi pozorovat', akoby žiaci nedisponovali potrebnými sociálnymi kompetenciami, ktoré sú v nejednom prípade len nedostatočne rozvinuté, čo môže byt' zapríčinené preceňovaním školského vzdelávania na úkor školskej a mimoškolskej výchovy, nedostatočnou alebo chýbajúcou rodinnou výchovou, iracionálnym využívaním prostriedkov modernej komunikácie na úkor bežnej „tvárou v tvár“" l'udskej komunikácie a d’alšími individuálnymi i sociálnymi faktormi. Absencia, resp. nízka úroveň rozvoja požadovaných sociálnych kompetencií sa môže prejavit’ aj v správaní 
a konaní žiakov, ktoré sa neraz odchyl'uje od spoločenskej normy, a učitel'om spôsobuje nemalé problémy.

Domnievame sa, že žiak, ktorý disponuje žiaducimi sociálnymi kompetenciami a za predpokladu eliminácie, príp. minimalizácie vplyvu iných nežiaducich osobnostných a sociálnych faktorov, je schopný sa správat' spoločensky korektne, v súlade s pravidlami školy i spoločnosti, t. j. bez symptómov výchovne problémového alebo narušeného správania.

Preto považujeme za dôležité pripomenút', že úlohou školy nie je len žiakov vzdelávat', ale ich aj vychovávat'. Kvôli zat'aženiu učitel'ov vyučovacou povinnost'ou a z nej vyplývajúcou administratívnou činnost'ou ${ }^{1}$, by bolo žiaduce, aby na všetkých školách pôsobili špecialisti, ako napr. sociálni pedagógovia, ktorí budú participovat' na napíňaní tejto úlohy. Ako príklad môže slúžit' aj projekt PRINED, realizovaný v našich podmienkach (viac o ňom: Hroncova, Emmerova et al., 2015: 205 - 206 a na stránke http://prined.mpc-edu.sk/).

\section{K pojmu kompetencia, kl’účová kompetencia a sociálna kompetencia}

V odbornej literatúre i vo všednej praxi sa často operuje s pojmami ako schopnost', spôsobilost', kapacita, zručnost' a i., ktoré sú tiež považované za synonymá pojmu kompetencia (Turek, 2003: 5). Treba ale poznamenat', že je potrebné odlišovat' kompetenciu od schopnosti či zručnosti žiaka (viac o tom napr. Lorinczova, Zovinec, 2016). E. Petlak (2004: 97) chápe pod kompetenciou ,právomoc, dosah právomoci, spôsobilost' vykonávat' istú činnost"“. J. Veteska a M. Tureckiova (2008: 25) definujú kompetenciu ako oprávnenie (formálnou autoritou sprostredkovanú moc/právomoc) jednotlivca konat' rozhodnutia, za ktoré by mal niest' aj zodpovednost'... alebo na strane druhej ako súbor znalostí, spôsobilostí, skúseností, metód, postupov a postojov, ktoré jednotlivec využiva $k$ úspešnému riešeniu rôznych úloh a životných situácií a ktoré mu tiež umožňujú osobnostne sa rozvíjat' a naplínat' jeho životné ašpirácie. I. Turek (2003: 5) odporúča vymedzenie kompetencie na behaviorálnom základe (od Schoonover Associates, 2001) ako „správanie (činnost' alebo komplex činností), ktoré charakterizuje vynikajúci výkon v niektorej oblasti činnosti“". Autor d'alej dodáva, že kompetenciu možno chápat' ako prienik vedomostí, zručností, motívov a postojov (Turek, 2003: 5). Každá kompetencia je kontextualizovaná (ide o to, že sa uplatňuje v určitom prostredí alebo v situácii), multidimenzionálna (to znamená, že je tvorená z viacerých ,zdrojov“, napr. informácie, poznatky, spôsobilosti, predstavy atd', zároveň však predpokladá efektívne narábanie s danými zdrojmi, ktoré sú prepojené so základnými dimenziami l'udského správania), definovaná štandardom (znamená to, že jej predpokladaná úroveň zvládnutia je určená vopred spolu so súborom výkonových kritérií) a má potenciál pre akciu a rozvoj, to znamená, že žiak nadobúda a rozvíja kompetencie v procese edukácie (Tremblay et al., 2002, in: Veteska, Tureckiova, 2008: 31 32).

1 O koordinátoroch prevencie na školách sa podobne píše v publikácii J. Hroncovej, I. Emmerovej et al. (2015: 143 - 144). 
H. Belz a M. Siegrist (2001: 166) sa zmieňujú o tzv. kl'účových kompetenciách, ktoré ,zahrňujú celé spektrum kompetencií presahujúcich hranice jednotlivých odborností. Sú výrazom schopnosti človeka správat' sa primerane situácii, v súlade sám so sebou, teda jednat' kompetentne“. I. Turek (2003: 25 - 32) radí medzi kl'účové kompetencie (žiakov) informačné kompetencie, učebné kompetencie, kognitívne kompetencie, interpersonálne (sociálne) kompetencie, komunikačné kompetencie a personálne kompetencie. Odporúčanie Európskeho parlamentu a rady z 18.12.2006 o klúčových kompetenciách pre celoživotné vzdelávanie sa vo svojej prílohe Klúčové kompetencie pre celoživotné vzdelávanie - európsky referenčný rámec zmieňuje o ôsmich kl'účových kompetenciách, a to komunikácia $v$ materinskom jazyku, komunikácia v cudzich jazykoch, matematická kompetencia a základné kompetencie voblasti vedy a techniky, digitálna kompetencia, kompetencia naučit' sa učit', spoločenské a občianske kompetencie, kompetencia iniciatívnosti a podnikavosti, kompetencia kultúrneho povedomia a vyjadrovania. Faktom však zostáva, že pri návrhoch kl'účových kompetencií $\mathrm{v}$ jednotlivých krajinách sa vychádzalo $\mathrm{z}$ rôznych kritérií, príp. z pohl'adu rôznych vied (viac o tom: Turek, 2003: 8 - 24).

Z vyššie uvedeného jednoznačne vyplýva, že sociálne kompetencie ako kl'účové kompetencie tvoria nedelitel'nú súčast' života integrovanej l'udskej bytosti. Podl'a M. Hupkovej (2014: 42) predstavuje sociálna kompetencia „kapacitu jednotlivca k regulácii vlastného správania (na úrovni kognícií, emócií i zjavného správania), ktorá umožňuje jednotlivcovi primeraným spôsobom vyjadrit' svoje emócie a potreby, efektívne zvládat' rozličné sociálne situácie a požiadavky v rámci sociálnej interakcie, ako aj dosahovat' osobné či interpersonálne ciele. Sociálna kompetencia je tu tiež na rozdiel od iných konceptov sýtená prosociálnym (pomáhajúcim), kooperatívnym (spolupracujúcim) a asertívnym (rešpektujúcim) správaním“. Obsahom sociálnej kompetencie je nielen komplex sociálnych spôsobilostí, príslušných sociálnych vedomostí a skúseností, ale tiež sociálnych vlastností, sociálnych motívov a postojov, ktoré sa môžu prejavit' v efektívnom konaní (Hupkova, 2014: $42-43)$.

E. Lorinczova a E. Zovinec (2016: 61 - 62) delia sociálne kompetencie na interakčné kompetencie, komunikačné kompetencie, organizačné kompetencie a behaviorálne spôsobilosti. Autori d’alej uvádzajú, že sociálne kompetencie určujú, ako sa človek bude správat' v konkrétnych situáciách a v konkrétnom sociálnom prostredí. Podl'a J. Vyrosta (2002, in: Hupkova, 2010: 18) je sociálna kompetencia situačne charakteristická a podmienená vývinovými hl'adiskami, pričom jej obsah tvoria napríklad aj tieto komponenty: efektívna komunikácia, schopnost' budovat' a udržiavat' vzt'ahy, efektívne riešenie sociálnych problémov, konštruktívne riešenie konfliktov, sebakontrola a sebamonitorovanie vlastného správania, rešpektovanie individuálnych odlišností, schopnost' rozlišovat' medzi sociálne pozitívnymi a negatívnymi vplyvmi peer skupín.

Na základe uvedeného možno predpokladat', že sociálne kompetencie ako kl'účové kompetencie predstavujú významný prvok v regulácii nežiaduceho správania žiakov na spoločensky želatel'né správanie. Dá sa očakávat', že sociálne kompetentný žiak bude viac sociálne prispôsobivý a jeho správanie 
sa nebude výrazne odchyl’ovat' od spoločenskej, resp. školskej normy, ktorou môže byt' napríklad vnútorný poriadok školy pre žiakov, i ked’, ako píše M. Veresova (2006, in: Hupkova, 2010: 18), kvalita sociálnej kompetencie ,je v behaviorálnom situačnom kontexte prediktorom tak sociálne kompetentného správania, ako aj sociálne nekompetentného správania“.

\section{Výchovné problémy a poruchy správania žiakov}

Domáce i zahraničné výskumy potvrdzujú, že problémové správanie žiakov má stúpajúci trend a čoraz závažnejšie podoby. Z českého prostredia uvádzame výskum S. Bendla (2004: 43 - 44), ktorý rozdelil priestupky žiakov do dvoch hlavných skupín, a to na nedisciplinovanost' voči učitel'om (škole), ako napr. drzost', vulgárnost', vandalizmus, šikana, krádeže, poškodzovanie vecí učitel'ov, drogy, fajčenie, alkohol, záškoláctvo, fyzické útoky, klamstvo, ohováranie, prepisovanie známok v žiackej knižke, nahlásenie bomby $\mathrm{v}$ škole, používanie mobilu cez vyučovanie... a nedisciplinovanost' voči (spolu)žiakom, ako napr. vulgárnost', šikana, krádeže, poškodzovanie osobných a školských vecí spolužiakov, ohováranie, provokácie, rozširovanie pornografie a i.

V. Labath (2009: 11) sa zmieňuje o dissociálnom správaní, ktoré označuje také prejavy správania, ktoré sú $\mathrm{v}$ nezhode alebo sú protikladom spoločenských, príp. (v krajných prípadoch) právnych noriem. Podl'a autora je toto správanie symptomaticky rôznorodé a má mnohofaktorové pozadie. V. Labath (2009: 32) radí medzi dissociálne poruchy správania 1) dissociálnu poruchu osobnosti, 2) pravé dissociálne správanie, t. j. dissociálny vývin (a/ dissociálne príznaky a b/ fixované dissociálne poruchy správania), 3) nepravé dissociálne správanie a 4) dissociálne správanie sociálnej skupiny.

$\mathrm{V}$ bežnej pedagogickej praxi sa však neraz stiera rozdiel medzi výchovným problémom a poruchou správania. Metodicko-informatívny materiál Žiak s poruchami správania vzákladnej a strednej škole (2013: 4), ktorý vypracoval Štátny pedagogický ústav a schválilo MŠVVaŠ SR, definuje poruchy správania „ako široké, etiologicky rôznorodé spektrum maladaptívneho správania, pričom jednotlivec je rezistentný voči bežnému výchovnému pôsobeniu a jedná sa o trvalejši ráz a prejav osobnosti “.

Medzinárodná klasifikácia chorôb (MKCH-10-SK-2016), účinná od 1.1.2018, popisuje $\mathrm{v}$ piatej kapitole duševné poruchy a poruchy správania, z ktorých vyberáme poruchy správania a emotivity so zvyčajným začiatkom $v$ detstve a počas dospievania ( $F 90$ - F98), medzi ktoré patrí hyperkinetická porucha, porucha správania (t. j. porucha správania viazaná na vztahy v rodine, porucha sociálneho správania pri chýbaní sociálnych väzieb, porucha sociálneho správania so zachovaním sociálnych väzieb, porucha správania s opozičným, vzdorovitým správaním, iná porucha správania a bližšie neurčená porucha správania), zmiešaná porucha správania a emotivity, porucha emotivity $\mathrm{v}$ detskom veku, porucha sociálneho fungovania so začiatkom $\mathrm{v}$ detstve a počas dospievania, tiková porucha, iná porucha správania a emotivity so zvyčajným začiatkom $\mathrm{v}$ detstve a počas dospievania. Výchovné problémy i poruchy správania žiakov môžu mat' rôzne podoby (symptómy), ako sme naznačili vyššie, ale aj rôzne príčiny. E. Ticha (2015: 
30 - 34), odvolávajúc sa aj na iných autorov, člení a popisuje príčiny špecifických porúch správania nasledovne:

1) zhladiska biologických teórií - negenetické (zjavné) faktory, ako prenatálne (napr. zdravotný stav matky, pôsobenie toxínov, nedonosenost', prenášanie a i.), perinatálne (napr. predčasný/komplikovaný pôrod, novorodenecká žltačka a i.) a postnatálne (napr. vírusové infekčné ochorenia, zvýšená rádioaktivita, úrazy a pod.) faktory, a genetické faktory;

2) zhl'adiska psychologických teórii - paralelné pôsobenie dispozícií k nevhodnému správaniu a (nesprávneho) spôsobu výchovy atd'.

Záverom autorka sumárne konštatuje, že špecifické poruchy správania môžu zapríčinit' viaceré faktory, ako „,hereditárne (genetické) dispozície, prenatálne a perinatálne faktory, deficity $v$ rovine neuroanatómie mozgu, deficity $\mathrm{v}$ rovine neurofyziológie mozgu, deficity $\mathrm{v}$ rovine neurochémie mozgu, diétne vplyvy, faktory rodinného prostredia“ (Ticha, 2008, in: Ticha, 2015: 34). Príčiny nešpecifických porúch správania triedi a popisuje E. Ticha (2015: 34 - 37), na základe práce Z. Michalovej (2004), M. Vagnerovej (1999) a D. Krejcirovej (1997), nasledovne:

1) biologické a osobnostné faktory - genetické dispozície, oslabenie a porucha CNS a i.;

2) psychologické faktory - porucha správania ako prejav hl'adania náhradného uspokojenia, ako volanie o pomoc, poruchy správania súvisiace s dlhodobou emočnou depriváciou, poruchy správania na základe disharmonického vývinu osobnosti, poruchy správania ako prejav inej psychickej poruchy (schizofrénia alebo depresia),

3) faktory užšieho (anomálny rodič, rodič s nedostatočne osvojenými morálnymi normami, neúplnost' rodiny, subdeprivačná skúsenost' jednotlivca a i.) a širšieho (vysoká nezamestnanost', nedostatok vzdelania, vplyv asociálnych skupín v dospievaní a pod.) sociálneho prostredia.

M. Zelina (2008: 4) uvádza, že dysfunkcia autoregulačného systému osobnosti sa môže podpísat' pod rôzne zlyhania človeka. Ako autor d'alej píše, sebaregulačný systém zasahuje do všetkých psychických procesov (myslenie, prežívanie, cítenie, rozhodovanie, sociálna interakcia a správanie), pričom zručnostiam sebaregulácie je možné sa naučit'. Preto M. Zelina (2008: 10) odporúča pri tvorbe preventívnych programov vychádzat' z modelu autoregulácie. Podl'a nášho názoru sebaregulačný systém osobnosti môže úzko súvisiet' aj so sociálnymi kompetenciami žiakov.

Vcelku teda možno konštatovat, že príčiny výchovných problémov, resp. porúch správania u žiakov treba hl'adat' vo vnútornom a vonkajšom prostredí žiaka. S. Fischer a J. Skoda (2014: 51 - 53) sa zmieňujú o dispozíciách biologických (u mužov napr. hladina testosterónu; zmeny v štruktúre alebo funkcii CNS; úraz alebo choroba; poškodenie kôry čelových lalokov; dysfunkcia serotoninergného systému; zmeny hladiny acetylcholínu a i.) a sociokultúrnych (sociálne učenie; vplyv spoločnosti a celého jej systému a i.). S. Bendl (2004: 83) člení faktory, reálne alebo potenciálne sa podiel'ajúce na nedisciplinovanom správaní žiakov v škole, do niekol'kých skupín - biologické, „duchovné“, sociálne, biologicko-sociálne, zdravotnicko-hygienické, fyzikálne, situačné, kombinované a neznáme faktory. 
Domnievame sa, že okrem vyššie uvedených príčin môžu nevhodné prejavy správania žiakov vzniknút' a d'alej sa rozvíjat' aj na báze nedostatočne rozvinutých alebo absentujúcich sociálnych kompetencií žiakov. V takom prípade by mohla byt' intervencia zo strany školy pomerne nenáročná. $O$ jej možnostiach sa zmieňujeme $v$ nasledujúcej kapitole.

\section{Nadobúdanie a rozvoj sociálnych kompetencií žiakov ako prevencia ich nežiaduceho správania $v$ škole a mimo školy}

Predchádzat' nežiaducemu správaniu žiakov v škole (i mimo nej) sa dá prostredníctvom širokého spektra preventívnych programov celoštátneho i lokálneho charakteru, ktoré sú zamerané, okrem iného, na rôzne zložky žiakovej osobnosti. Niektoré preventívne programy sledujú nadobúdanie nových vedomostí o spoločensky nežiaducom jave, iné sa zas zameriavajú na emocionálnu a psychomotorickú stránku osobnosti žiaka, a sledujú rozvoj jeho sociálnych kompetencií. Ako príklad môže slúžit’ aj známy preventívny program Cesta k emocionálnej zrelosti, ktorý tvoria tri klúčové moduly, a to porozumenie sebe samému (modul A), skvalitnenie klúčových kompetencií (modul B) a cesta k emocionálnej zrelosti (modul C) (Matula, 2011: 5). Ciel'om predmetného programu je prispiet' „k postupnému uvedomovaniu si seba samého (sebauvedomeniu) a vadväznosti na to $\mathrm{k}$ skupinovému prežívaniu najpodstatnejších znakov emocionálnej zrelosti“ (Matula, 2011: 52). Na rozvíjanie sociálnych zručností žiakov možno využit’ aj tieto slovenské a zahraničné programy: Aki sme?, Expoprogram, Vieme, že... 262 (holandský projekt modifikovaný na slovenské podmienky), The ACCEPTS, Classwide Antecedent Modifications, Connecting with others, Second Step, Skillstreaming (viac o tom: Lorinczova, Zovinec, 2016: 110 - 133).

Jedným z nástrojov, ktorým možno predchádzat' výchovným problémom žiakov v škole, je aj výcvik sociálnych a personálnych spôsobilostí. Len na okraj dodávame, že výcvik predstavuje popri vzdelávaní a výchove jeden z troch pilierov edukácie (viac o tom: Svec, 2008: 89). Žial', edukačná prax nám ukazuje, že dominantou súčasnej školy je vzdelávanie, pričom výchova a výcvik obsadili druhú priečku $v$ hierarchii edukačných procesov, hoci je ich význam z hl'adiska integrity osobnosti žiaka zjavný.

M. Hupkova (2010: 6) chápe výcvik (tréning) sociálnych spôsobilostí „ako praktickú činnost', ktorá cielene podporuje proces sociálneho učenia založeného na osobnej interpersonálnej skúsenosti a na sprievodnom emocionálnom zážitku“. Medzi základné ciele, ktoré možno sledovat' odborným výcvikom sociálnych a personálnych spôsobilostí, radíme zvýšenie schopnosti vnímat' sociálnu skutočnost', prehíbenie snahy o autoreguláciu, zmenu nežiaducich stereotypov, funkčné vyjadrovanie pocitov, ujasňovanie si vlastných motívov, sebaakceptovanie a akceptovanie druhých, skupinové hodnoty, interpersonálnu otvorenost' (Hermochova, 1988, in: Hupkova, 2010: 50 - 51). Žiaci si vd’aka výcvikom osvojujú korektné vzorce správania, nové sociálne spôsobilosti, učia sa kooperovat'a ako reagovat' v krízových i konfliktných situáciách a pod. Predmetné výcviky by sa mali realizovat' záväzne (ako obligatórna súčast' plánu práce školy/triedy) $\mathrm{v}$ rámci vol'ných hodín $\mathrm{v}$ rozvrhu, triednických hodín alebo 
v rámci samostatného (týždenného/mesačného) mimovyučovacieho programu školskej triedy (Hatar, 2016: 213).

Je teda nesporné, že nadobúdaním a rozvíjaním sociálnych kompetencií žiakov aj prostredníctvom výcviku sociálnych a personálnych spôsobilostí možno predchádzat' ich nežiaducemu správaniu v škole a mimo školy. I. Turek (2003: 7) uvádza, že osvojovanie a zdokonal'ovanie kl'účových kompetencií (vrátane sociálnej kompetencie) sa uskutočňuje v procese celoživotného učenia sa a v rôznych inštitúciách (škola, rodina, zamestnanie, kultúrny život a pod.). Autor d’alej dodáva, že „kl’účové kompetencie sú nadpredmetové, neviažu sa na konkrétny obsah učiva, môžu si ich žiaci osvojovat' v ktoromkol’vek predmete (aspoň niektoré $\mathrm{z}$ nich)“, pričom za najvhodnejšie koncepcie na osvojovanie si kl'účových kompetencií u žiakov autor považuje projektové vyučovanie, kooperatívne vyučovanie a problémové vyučovanie (Turek, 2003: 33 - 34).

Účinným nástrojom na nadobúdanie a rozvíjanie potrebných sociálnych kompetencií žiakov je aj medzigeneračné učenie. M. Rabusicova, L. Kamanova a K. Pevna (2011: 167 - 168), odvolávajúc sa na viaceré zahraničné výskumy (pramene), uvádzajú, že medzigeneračné programy sú obohatením tak pre staršiu, ako aj pre mladšiu generáciu, u ktorej možno zaznamenat':

- zmenu postojov k starším, zlepšovanie vzt’ahov a prekonávanie bariér medzi obidvomi generáciami,

- redukciu sociálnej segregácie a rast sociálnej inklúzie,

- podporu sociálneho a osobnostného progresu mladých l'udí, ale i seniorov,

- utužovanie zdravotného stavu, zvyšovanie sebadôvery a znižovanie sociálnej izolácie obidvoch generácií,

- dosahovanie lepších výsledkov v škole, zlepšenie zdravia a odolnosti,

- nárast sociálnej zodpovednosti mladých l'udí a znižovanie predpokladov k sociálno-patologickému správaniu.

Domnievame sa, že tento spôsob nadobúdania sociálnych kompetencií u žiakov je v našich podmienkach stále inovatívny, ukrýva v sebe potenciál zaujat' a motivovat' žiakov, a zároveň im nedirektívne sprostredkovat' nové fakty, poznatky.

\section{Namiesto záveru}

J. Veteska (2011: 11) konštatuje, že „V súčasnosti zaznamenávame v mnohých oblastiach l'udských činností rýchly vývoj, a to ako technologický, tak znalostný. Za určitých podmienok môže byt’ dnešná doba plná možností a nádejí, ale rovnako neistôt, nerovných šancí, individualizmu a sociálneho nepokoja“. Preto je aktuálna výzva R. Jedlicku (2011: 14), ktorý uvádza, že je potrebné viest' žiakov tak k asertívnemu správaniu a spoločenskému sebapresadzovaniu, ako aj k rozvoju pocitu spolupatričnosti, kohézie a k schopnosti znášat' (a možno dodat' aj zvládat') nepriaznivé situácie, ktoré život prináša. Autor d’alej píše, že u žiakov nie je l'ahké dosiahnut' určitú dávku sebadisciplíny, schopnosti odriekania a prirodzenej kontroly konania (Jedlicka, 2011: 14). Domnievame sa, že aj 
uvádzané schopnosti a vlastnosti súvisia so sociálnymi kompetenciami žiakov a idú ruka $\mathrm{v}$ ruke $\mathrm{s}$ nevhodným správaním, ktoré sa môže u žiakov objavit'.

Na základe vyššie uvedeného možno prijat' hypotézu, že prostredníctvom rôznych sociálnych (preventívnych) programov či edukačných aktivít (napr. výcvik sociálnych spôsobilostí, záujmová výchova a vzdelávanie a pod.), ktoré vedú, resp. budú viest' kvalifikovaní edukační pracovníci, je možné docielit' nadobudnutie a rozvoj potrebných sociálnych kompetencií u žiakov, ktoré im budú bránit' v nevhodnom správaní v škole i mimo nej (tzv. sociálne korektné správanie a konanie).

Ako sme už uviedli, učitelia neraz nemajú čas napíňat' podstatu výchovnej a socializačnej ${ }^{3}$ funkcie školy, a preto sa javí rozumné angažovat' v škole d’alších edukačných pracovníkov, ktorí by mali $\mathrm{v}$ kompetencii výlučne sociálno-výchovnú prácu so žiakmi.

\section{Bibliographic references}

BAKOSOVA, Z. 2005. Socialna pedagogika ako zivotna pomoc. Bratislava: STIMUL. 219 p. ISBN 80-89236-00-6.

BELZ, H. - SIEGRIST, M. 2001. Klicove kompetence a jejich rozvijeni. Vychodiska, metody, cviceni a hry. Praha: Portal. 376 p. ISBN 80-7178-4796.

BENDL, S. 2004. Kazenske problemy ve skole. Praha: TRITON. 264 p. ISBN 80-7254-453-5.

264 BENDL, S. - HANUSOVA, J. - LINKOVA, M. 2016. Zak s problemovym chovanim. Cesta institucionalni pomoci. Praha: TRITON. 112 p. ISBN 97880-7387-703-3.

BRAJEROVA, L. 2013. Nahradna vychovna starostlivost a proces osamostatnovania adolescentov. Dizertacna praca. Nitra : PF UKF. 239 p.

EDELSBERGER, L. - KABELE, F. 1988. Specialni pedagogika pro ucitele prvniho stupne zakladni skoly. Praha: SPN. 176 p.

EMMEROVA, I. 2012. Preventivna a socialno-vychovna praca $\mathrm{s}$ problemovymi detmi a mladezou. Banska Bystrica: UMB. 142 s. ISBN 97880-557-0463-0.

EMMEROVA, I. 2010. Socialno-patologicke javy v slovenskych rodinach. In VISNOVSKY, L. - HRONCOVA, J. et al. Slovenska rodina v kontexte transformacnych premien. Banska Bystrica: UMB, pp. 69-89. ISBN 978-80557-0034-2.

FISCHER, S. - SKODA, J. 2014. Socialni patologie. Zavazne socialne patologicke jevy, priciny, prevence, moznosti reseni. Praha: GRADA. 232 p. ISBN 978-80-247-5046-0.

2 B. Kraus (2008: 102) uvádza, že škola by mala klást' menší akcent na odovzdávanie poznatkov (t. j. kognitívnu zložku) a väčší na celkový rozvoj osobnosti, najmä jej emocionálnej a konatívnej zložky.

3 „Ako zásadné sa javí vyzbrojit' mladých l'udí silou nepodliehat' najrôznejším „nástrahám“, väčšou zodpovednost’ou za konanie svoje i druhých a posilňovat' $v$ mladej generácii altruistické tendencie a solidaritu“ (Kraus, 2008: 102). 
HARTL, P. - HARTLOVA, H. 2010. Velky psychologicky slovnik. Praha: Portal. 800 p. ISBN 978-80-7367-686-5.

HATAR, C. 2017. Personalne zabezpecenie detekcie, prevencie a riesenia kyberagresie u ziakov zakladnych skol. In HOLLA, K. et al. Prevencia kyberagresie a kybersikanovania. Nitra: UKF, pp. 83-99. ISBN 978-80-5581210-6.

HATAR, C. 2016. Socialny pedagog ako akter triednej a skolskej klimy. In Slavonic Pedagogical Studies Journal, roc. 5, c. 2, pp. 206 - 216. ISSN 13398660.

HATAR, C. 2015. Symptomatika a etiopatogeneza agresivneho spravania ziakov. In HANULIAKOVA, J. et al. Klima skoly a agresivita ziakov v empirickom kontexte. Dubnica nad Vahom: DTI, pp. 30-54. ISBN 978-8089732-62-3.

HATAR, C. - JEDLICKOVA, P. 2017. Prevencia a kurativa kyberagresie prostrednictvom medzigeneracneho ucenia. In SZCZUREK-BORUTA, A., JAS, K. (eds.). Czlowiek wykluczony i czlowiek w sytuacji zagrozenia wykluczeniem spolecznym, edukacyjnym, kulturowym - wyzwania, powinnosci pedagogiki, zadania. Torun: Wydawnictwo Adam Marszalek, pp. 29 - 43. ISBN 978-83-8019-695-7.

HOLLA, K. 2010. Elektronicke sikanovanie - nova forma agresie. Bratislava: Iris. 92 p. ISBN 978-80-89256-58-7.

HOTAR, V. - PASKA, P. - PERHACS, J. et al. 2000. Vychova a vzdelavanie dospelych. Andragogika. Terminologicky a vykladovy slovnik. Bratislava: SPN. 547 p. ISBN 80-08-02814-9.

HRONCOVA, J. - EMMEROVA, I. - CIMPRICHOVA GEZOVA, K. 2015.

Socialno-vychovna praca $\mathrm{s}$ rodinou $\mathrm{z}$ aspektu socialnej pedagogiky. Banska Bystrica: UMB. 180 p. ISBN 978-80-557-0926-0.

HRONCOVA, J. - EMMEROVA, I. et al. 2012. Socialny pedagog v skole. Banska Bystrica: UMB. 242 s. ISBN 978-80-557-0465-4.

HRONCOVA, J. - EMMEROVA, I. et al. 2009. Socialna pedagogika. Vyvoj a sucasny stav. Banska Bystrica : UMB. 276 p. ISBN 978-80-8083-819-5.

HRONCOVA, J. - EMMEROVA, I. et al. 2015. Socialny pedagog v skole v teoretickej reflexii a praxi. Banska Bystrica: UMB. 287 p. ISBN 978-80-5570957-4.

HUPKOVA, M. 2010. Rozvijanie socialnych sposobilosti v pomahajucich profesiach. Nitra: UKF. 334 p. ISBN 978-80-8094-704-0.

HUPKOVA, M. 2014. Socialna kompetencia ako jedna z klucovych kompetencii (socialneho) andragoga. In Pozna doroslosc - doswiadczenia, problemy, wsparcie spoleczne i edukacyjne. Dabrowa Gornicza: WSB, p. 41 - 52. ISBN 978-83-62897-67-4.

JEDLICKA, R. 2017. Psychicky vyvoj ditete a vychova. Jak porozumet socializacnim obtizim. Praha: Grada. 280 p. ISBN 978-80-271-0096-5.

JEDLICKA, R. 2011. Vychovne problemy s zaky z pohledu hlubinne psychologie. Praha : Portal. 248 p. ISBN 978-80-7367-788-6.

JEDLICKOVA, P. 2017. Medzigeneracne ucenie $\mathrm{v}$ rodinnom prostredi ako prevencia agresivneho spravania u deti. Nitra: UKF. 108 p. ISBN 978-80558-1178-9. 
KOMARIK, E. 1999. Pedagogika emocionalne a socialne narusenych. Bratislava: UK. 192 p. ISBN 80-223-1394-7.

KOSOVA, B., KASACOVA, B. 2007. Zakladne pojmy a vztahy v edukacii. Banska Bystrica: UMB. 162 p. ISBN 978-80-8083-525-5.

KRAUS, B. 2008. Zaklady socialni pedagogiky. Praha: Portal. 216 p. ISBN 978-80-7367-383-3.

LABATH, V. 2009. Dissocialne poruchy spravania. Bratislava: OZ Socialna praca. 80 p. ISBN 978-80-89185-31-3.

LABATH, V. et al. 2001. Rizikova mladez. Moznosti potencialnych zmien. Praha: SLON. 157 p. ISBN 80-85850-66-4.

LORINCZOVA, E. - ZOVINEC, E. 2016. Socialne kompetencie ziakov v diskurze 21. storocia. Nitra: UKF. 150 p. ISBN 978-80-558-1124-6.

LOVAS, L. 2010. Agresia a nasilie. Psychologia ludskej agresie a jej podoby v domacom prostredi, v skole, v praci, vo vazniciach a v sporte. Bratislava: Ikar. 200 p. ISBN 978-80-551-1752-2.

LULEI, M. - LABATH, V. 2016. Delikvencia v kontexte rizikoveho vyvinu. ISRD 3. Bratislava: UK. 115 p. ISBN 978-80-223-4235-3.

MASARIKOVA, A. - MASARIK, P. 2002. Vybrane kapitoly z pedagogiky volneho casu. Nitra: UKF. 208 p. ISBN 80-968735-0-4.

MATULA, S. 2011. Emocionalna zrelost - siedma klucova kompetencia. Bratislava: MPC. 76 p. ISBN 978-80-8052-403-6. [cit. 2018-07-09]. Available online: https://www.komposyt.sk/pre-odbornikov/psychologickacinnost/preview-file/matula_emocionalna-zrelost-437.pdf

Medzinarodna klasifikacia chorob. [cit. 2018-07-09]. Available online:

http://www.nczisk.sk/Standardy-v-zdravotnictve/Pages/Medzinarodna-

klasifikacia-chorob-MKCH-10.aspx

NOVOTNA, M. - KREMLICKOVA, M. 1997. Kapitoly ze specialni pedagogiky pro ucitele. Praha: SPN. 115 p. ISBN 80-85937-60-3.

Odporucanie Europskeho parlamentu a rady z 18.12.2006 o klucovych kompetenciach pre celozivotne vzdelavanie a Klucove kompetencie pre celozivotne vzdelavanie - europsky referencny ramec. [cit. 2018-07-11]. Available online:

http://nuczv.sk/images/dokumenty_na_stiahnutie/europske_svetove_dokume nty/klucove_kompetencie_pre_celozivotne_vzdelavanie.pdf

ONDREJKOVIC, P. et al. 2009. Socialna patologia. Bratislava: VEDA. 580 p. ISBN 978-80-224-1074-8.

PETLAK, E. 2004. Kompetencie ucitela. In HUPKOVA, M., PETLAK, E. Sebareflexia a kompetencie v praci ucitela. Bratislava: IRIS, pp. $97-111$. ISBN 80-89018-77-7.

PETLAK, E. 1997. Vseobecna didaktika. Bratislava: Iris. 274 p. ISBN 8088778-49-2.

PRINED - Narodny projekt inkluzivnej edukacie. [cit. 2018-07-09]. Available online: http://prined.mpc-edu.sk/

RABUSICOVA, M. - KAMANOVA, L. - PEVNA, K. 2011. O mezigeneracnim uceni. Brno : MU. 208 p. ISBN 978-80-210-5750-0.

RICAN, P. 1998. Agresivita a sikanovanie medzi detmi. Trnava: Educatio. 92 p. ISBN 80-967532-2-3. 
Smernica c. 36/2018 k prevencii a rieseniu sikanovania deti a ziakov v skolach a skolskych zariadeniach. [cit. 2018-09-27]. Available online:

http://www.minedu.sk/data/att/13481.pdf

SVEC, S. 2008. Anglicko-slovensky lexikon pedagogiky a andragogiky. Bratislava: Iris. 323 p. ISBN 978-80-89256-21-1.

TICHA, E. 2015. Etiologia poruch spravania. In TICHA, E. (ed.). Teoreticke vychodiska poruch spravania. Bratislava : UK, s. 29 - 39. ISBN 978-80-2233994-0. [cit. 2018-07-09]. Available online:

http://www.poruchyspravania.sk/files/upload/files/Ticha\%28Ed.\%29_2015\% 281\%29.pdf

TICHA, E. - KOVACOVA, B. 2015. Uvod do problematiky poruch spravania. In TICHA, E. (ed.). Teoreticke vychodiska poruch spravania. Bratislava : UK, pp. 8 - 28. ISBN 978-80-223-3994-0. [cit. 2018-07-09]. Available online:

http://www.poruchyspravania.sk/files/upload/files/Ticha\%28Ed.\%29_2015\% 281\%29.pdf

TUREK, I. 2003. Klucove kompetencie. Bratislava : MPC. 40 p. ISBN 808052-174-3.

TVRDIK, M. 2013. Socialny pedagog v systeme socialno-edukacnej starostlivosti o vychovne problemovu mladez. Dizertacna praca. Nitra : PF UKF. 135 s.

VALENTA, M. et al. 2015. Slovnik specialni pedagogiky. Praha : Portal. 320 s. ISBN 978-80-262-0937-9.

VASEK, S. et al. 1995. Specialna pedagogika. Terminologicky a vykladovy slovnik. Bratislava : SPN. 245 p. ISBN 80-08-00864-4.

VAGNEROVA, M. 2000. Vyvojova psychologie. Detstvi - dospelost - stari. Praha : Portal. 522 p. ISBN 80-7178-308-0.

VETESKA, J. 2011. Promeny skolniho vzdelavani v biodromalnim kontextu. Praha: Verlag Dashofer. 180 p. ISBN 978-80-86897-39-4.

VETESKA, J. et al. 2017. Kompetence studentu a absolventu skol teoreticka vychodiska a priklady dobre praxe. Praha: CAS. 179 s. ISBN 97880-906894-0-4.

VETESKA, J. - TURECKIOVA, M. 2008. Kompetence ve vzdelavani. Praha: Grada. 159 p. ISBN 978-80-247-1770-8.

Zakon c. 317/2009 Z. z. o pedagogickych zamestnancoch a odbornych zamestnancoch v zneni neskorsich predpisov. [cit. 2019-02-18]. Available online: https://www.slov-lex.sk/pravne-predpisy/SK/ZZ/2009/317/20180101

Zakon c. $245 / 2008$ Z. z. o vychove a vzdelavani v zneni neskorsich predpisov. [cit. 2019-02-18]. Available online:

https://www.slov-lex.sk/pravne-predpisy/SK/ZZ/2008/245/20190102

ZELINA, M. 2008. Teoria autoregulacie - mozne vychodisko pre tvorbu preventivnych programov. In Prevencia, roc. 7, c. 3, pp. 3 - 11. ISSN 13363689.

ZELINA, M. 2004. Teorie vychovy alebo hladanie dobra. Bratislava : SPN. 231 p. ISBN 80-10-00456-1.

Ziak s poruchami spravania $\mathrm{v}$ zakladnej a strednej skole. Metodickoinformativny material. [cit. 2018-07-09]. Available online: https://www.minedu.sk/data/att/7771.pdf 
doc. PaedDr. Ctibor Határ, PhD.

Department of Education

Faculty of Education

Cotantine the Phiosopher University

Drážovská 4

94974 Nitra

E-mail: chatar@ukf.sk

doc. PhDr. Rastislav Rosinský, PhD.

Ústav romologických štúdií FSVaZ UKF

The Faculty of Social Sciences and Health Care

Cotantine the Phiosopher University

Kraskova 1

94974 Nitra

rrosinsky@ukf.sk 